\title{
GIVE THE WHOOPING CRANES "SAFE PASSAGE"
}

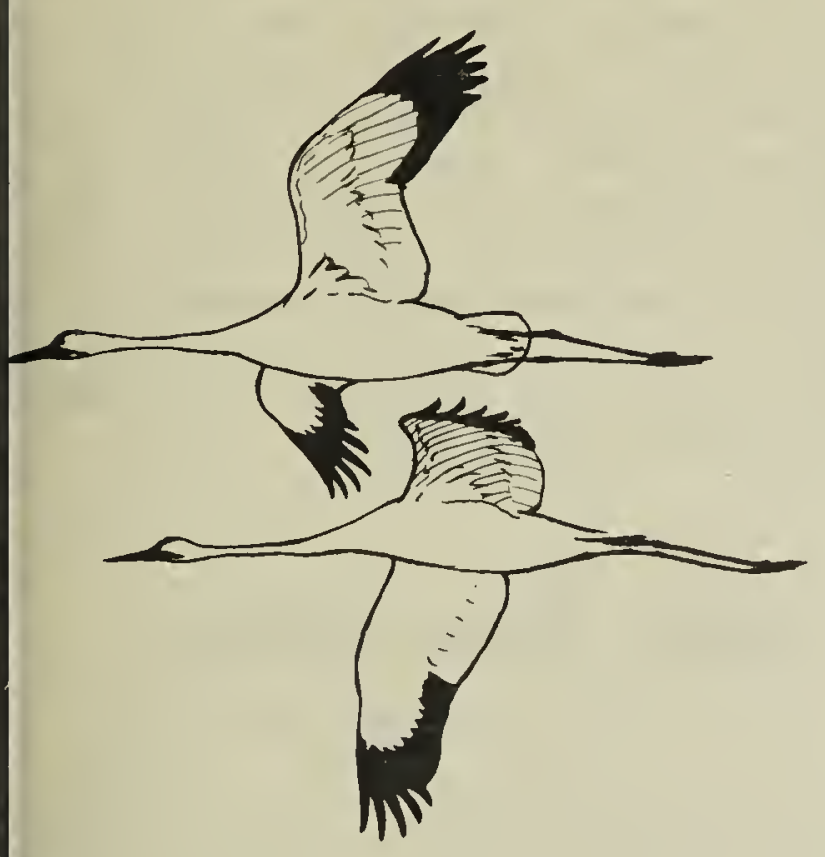

As the BLUE JAY goes to press it the beginning of the fall migation season, we again ask our readrs to help give the Whooping Cranes "safe passage" on their way south to he Aransas National Wildlife Refige.

Last April, 21 Whoopers left the Aransas Refuge in small groups and egan the long flight north to their reeding grounds in Wood Buffalo National Park. Three birds remained $n$ the refuge for the summer-one dult male which had spent the win$\epsilon r$ on the nearby King Ranch, and pair of one or two-year-old birds. Jpon the recommendation of the Whooping Crane Advisory Comnittee, the adult male was captured in July 2 as a possible mate for the aptive female bird in the custody of he San Antonio Zoological Society. Infortunately, this bird collapsed and died on the day of his capture.

Meanwhile, two young Whooping ranes are being successfully raised $n$ the New Orleans Zoo under the upervision of an aviculturist, George cott, of the New York Zoological ociety, and enccuraging reports are oming from the breeding grounds. Carly in June, N. S. Novakowski, iclogist with the Canadian Wildlife service stationed at Fort Smith, N.W.T., sighted nine cranes in the Dass River area of Wood Buffalo National Park, five which appeared o be on nests. The last report avilable from Novakowski (July 15) recorded observations made during a a flight on July 12: two pair adults, both with one young of the year, one adult which appeared to be sitting on a nest, and one adult from the pair (with one young) seen July 5-i.e. indications of three young.

There were practically no reports of Whooping Cranes in Saskatchewan this spring, probably because bad weather in the south-central States delayed migration and made stopovers fewer. However, reports were later received of one bird (possibly two) spending the summer in Saskatchewan. The first crane reported was seen near Keystown on June 23 by Fred Lahrman of the Museum Staff, and again on June 24 by Lahrman and Rex Schmidt (U.S. Fish and Wildlife Service). According to local people, this crane had been in the area for approximately three weeks. It was not seen in the area when a check was made June 25 . The second report came from Last Mountain Lake where a crane was seen on June 28 (at a distance of 350 feet) as it landed on a small island and rested for a few minutes before flying off again to the west (Dr. Stuart Houston, S. R. Belcher, Margaret Belcher). For almost a month after this date, reports of a lone crane in the same area (probably the bird observed by Houston) came from R. Blackwood, Conservation Officer, Imperial, and Arthur Perry, Nokomis (who observed the bird near the Perry farm on the lake west of Govan).

Speaking about the present status of the Whooping Crane, Fred Bard, Director of the Saskatchewan Museum and one of the twelve members of the Whooping Crane Advisory Committee, emphasized two important points. First, we must not, because of encouraging reports from the nesting grounds, relax our vigilance. Secondly, we should give immediate consideration to a management programme, since $50 \%$ of the potential hatch is lost on the breeding grounds with the cranes in the wild. Because he is strongly in favour of a management programme, Mr. Bard feels that the death of the crane captured last July was extremely unfort- 
unate. We dcn't know fully the circumstances of the attempted capture, nor the cause of the bird's death, but this incident is greatly to be regretted since it will be pointed to eagerly by the critics of a management scheme.

For those people watching for Whooping Cranes in migration this fall, Mr. Bard gave the following pointers. Examine carefully the areas where Sandhills congregate for migration. During the critical first week or two in October, when Sandhills are migrating, keep binoculars handy and scan each migrating flock. Check and double check to be sure that any bird seen with Sandhills which seems white when reflecting light is still white when back-lighted. If Whooping Cranes are seen feeding in the stubble (and therefore likely to remain for two or three days), telephone report to the museum; otherwise, submit reports by letter. Finally, remember the Whooping Cranes are not likely to be seen in large flocks-groups are not usually larger than five or six.

\title{
Observations at a Garter Snake Hibernaculum
}

\author{
By ROBERT W. NERO, Saskatchewan Museum of Natural History
}

Occasional reports of large concentrations of snakes have been received by the Museum for many years but until now none of these sites has been examined. On April 29, 1957, Mr. Tom Gentles of Regina gave us a detailed description of a "snake hill" found by him on the previous day near Estevan, Saskatchewan: Since a trip to this vicinity had already been scheduled for other purposes, we were able to verify this report on the following day. Roy G. Young and LeRoy A. Faibish of the Department of Natural Resources, Fred G. Bard, and the author made up the party which visited the site. We arrived at the spot described by Mr. Gentles on the second terrace on the south side of the Souris River valley a few miles southeast of Estevan, at noon on a hot bright day. It was at once clear that our informant had not been exaggerating in his description of a mutitude of snakes. In an hour and a half we saw at least 500 snakes, all of which were apparently Redsided Garter Snakes (Thamnophis sirtalis parietalis).

A small gulley about 100 feet long, 20 feet wide at the widest part and about 10 feet deep was the centre of attraction. This gulley was evidently the result of a cave-in over a burnt-out coal mine shaft. It was fairly open for the most part with a verticle exposure of burned or rather baked shale along the west slope at the upper end. This exposure appeared to be the actual den-site, the many vertical and horizontal crevices evidently offering ideal conditions for a hibernaculum. (Fig. 1) Snakes were numerous on the surface above the den-site and in the bushy area at the base of the gulley as well as in the actual gulley but only a few were found in other nearby pits and gullies. Abcut 120 snakes were first located beneath a clump of snowberry (Symphoricarpos sp.). Many were on the ground in the shade of these bushes but others rested in the tops of the brush and these moved quite rapidly along on the branches: At two places beneath the bushes snakes were found in writhing masses of 30 or more each. It was noticed that when the snakes were disturbed they moved rapidly away but tended to return to their origina locations. In places beneath the snowberry the leaves and twig formed windrows around bare spots evidently the result of the sweepin: movement of many snakes. This wa particularly evident on the mor sloping portions of the area.

On the ledge beneath the "cliff" cluster of about 60 snakes was foun (Fig. 2). During the 20 to 30 minute of observation of this group other moved out from the cracks unt about twice as many were presen In the bottom of the gulley at thi point another mass was found con taining at least 30 individuals.

soon became apparent that the mem bers of each of the masses which w had under observation tended to sta together as they moved about follow ing disturbance. Individuals whic became separated quickly returned the main mass. Furthermore, each masses contained one large membe 